\title{
BIBLIOGRAFIA SOBRE A TELENOVELA BRASILEIRA
}

\section{LIVROS}

CLAIR, Janete. Pai herói. Adaptação de Eduardo Bosato. Rio de Janeiro: Rio Gráfica, 1985. 144p.

Telenovela de Janete Clair, adaptada por Eduardo Borsato e levada ao ar no ano de 1979, no horário das 20h, pela Rede Globo. A história se desenrola em torno do personagem principal, André Cajarana, que busca provar a inocência de seu pai. Além disso, André se divide entre o amor de duas mulheres, com situações de classe e de personalidades completamente diferentes.

Palavras-chave: adaptação literária/ Janete Clair/ amor filial/ Pai herói

Loc. Doc. ${ }^{1}$ : NPTN/ECA/USP

SOUZA, Lícia Soares de. Représentation et idéologie: les téléromans au service de la publicité (Representação e ideologia: os teleromances a serviço da publicidade). Montreal: Les Éditons Balzac, 1994. 275p.

Esta obra propõe uma leitura dos folhetins televisivos colocando em relevo a produção da Rede Globo, que já exportou suas séries para mais de 50 países. Ela interroga os conceitos de representação e ideologia e, com a ajuda da semiótica, destaca os instrumentos necessários para descrever as modalidades de introdução de um discurso publicitário na ficção narrativa.

Pallavras-chave: publicidade/ representação/ ideologia

A AUTORA
Anamaria Fadul
Professora Titular do Departamento de
Comunicações e Artes da ECA-USP e
Coordenadora do Núcleo de Pesquisa de
Telenovelas (NPTN) deste Departamento.

1. Localização de Documento no Núcleo de Pesquisa de Telenovela (NPTN), Departamento de Comunicações e Artes da ECA-USP, no endereço: Av. Prof. Lúcio Martins Rodrigues, 443 - Bloco Central, $2^{\circ}$ andar, sala B-6 - Cidade Universitária - CEP 05508-900 - São Paulo, SP. Telefax: (011) 818-4326. 


\section{CAPÍTULOS DE LIVROS}

SARQUES, Jean Jorge. A discriminação sexual da telenovela: sua influência sobre a mulher brasileira. In: MELO, José Marques de. (coord.) Teoria e Pesquisa em Comunicação: panorama latino-americano. São Paulo: Cortez/INTERCOM/CIID, 1983. p.219-227.

A autora analisa a importância da telenovela no processo de reprodução da ideologia sexual da mulher. Tem por objetivo verificar quais valores sexuais eram assumidos pelas telespectadoras de classes sociais diferentes e as contradições entre ideologia e prática. Sempre a partir de uma novela-referência, neste caso, Os Gigantes, de Lauro César Muniz, a autora busca, também, a inter-relação desses valores com fatores sociais de classe, educação familiar e religiosa.

Palavras-chave: ideologia sexual/ mulher/ classes sociais/ educação familiar/ educação religiosa

Loc. Doc.: BT/ECA/USP

N. Cham. ${ }^{2}: 301.16 / \mathrm{M} 528 \mathrm{t}$

ANTOLA, Lívia; ROGERS, Everett. Televisión en America Latina. Chasqui - Revista Latinoamericana de Comunicación. Quito: CIESPAL, n.9, 1984. p.10-16.

Os autores, a partir da análise dos dados de produção, importação e exportação e de índices de audiência dos programas televisivos de cinco países latino-americanos: Argentina, Brasil, Peru, México e Venezuela, apontam para um novo padrão para os mercados de programas de língua hispânica. Os principais problemas considerados são: como a telenovela na América Latina desenvolveu sua forma atual; como as telenovelas substituíram os programas importados da televisão americana na América Latina e, por último, quais são as direções do fluxo de telenovelas de país a país na América Latina.

Palavras-chave: América Latina/ produção/ importação/ exportação/ Rede Globo/ Brasil

Loc. Doc.: BT/ECA/USP

N. Cham.: 301.16

CALAZANS, Flávio Mário de Alcântara. Propaganda subliminar multimídia. Anuário de Inovações em Comunicações e Artes. São Paulo: ECA-USP, 1990. p.343-353.

Analisa a propaganda subliminar com o objetivo de identificar novas tecnologias de envio de mensagens subliminares. Constata a defasagem da bibliografia em idioma português sobre esse tema. Descreve os mecanismos de percepção subliminar e as várias aplica-

2. Número de chamada do documento na Biblioteca da ECA-USP. Av. Lúcio Martins Rodrigues, 443 - Fone: (011) 818-4047. São Paulo-SP - CEP 05508-900 
ções na multimídia. Destaca o merchandising como o recurso de propaganda subliminar utilizado nas telenovelas brasileiras. Apresenta também aspectos relacionados com a ética na propaganda.

Palavras-chave: recepção/ ética da comunicação/ propaganda subliminar/merchandising Loc. Doc.: BT/ECA/USP

N. Cham.: PR 301. 16

MAZZIOTTI, Nora. Telenovelas latino-americanas: deslocamentos na textualidade do gênero. In: BORELLI, Sílvia Helena Simões. Gêneros ficcionais, produção e cotidiano na cultura popular de massa. São Paulo: Intercom/CNPq/Finep, 1994. p.11-18 (Coleção GT's Intercom)

Descreve as transformações da textualidade em várias novelas latino-americanas recentes e as modificações ocorridas no gênero. Enfoca a ruptura das regras desse gênero e sua mistura com todos os demais, a incorporação de novos temas e a referência a problemas sociais. Trata, também, da presença das telenovelas no mercado televisivo europeu e sua implicação na produção e na recepção.

\section{DISSERTAÇÃO}

ELIAS, Maria de Fátima Falia. O adolescente diante da telenovela: uma análise das vivências rurais e urbanas na cidade de Piracicaba. São Bernardo do Campo - SP: Instituto Metodista de Ensino Superior, 1995. 198p. (Dissertação de Mestrado)

Este estudo busca entender qual é a participação da telenovela no mundo dos adolescentes. Objetiva mostrar a importância de outras instituições socializadoras, como família, sociedade, escola e amigos, entre outras, nas formas de ver e decodificar esta programação. Os adolescentes foram pesquisados tanto no meio urbano como no rural, tendo em vista esclarecer como o adolescente, dentro de contextos sociais diferenciados, se posiciona diante da estrutura ficcional apresentada pela telenovela brasileira.

Palavras-chave: adolescentes/ urbana/ rural/ recepção

Loc. Doc.: NPTN/ECA/USP 